\title{
Effect of acetylation treatment on surface modified tapioca starches
}

\author{
Shaari, S., Samsudin, H. and *Uthumporn, U. \\ Food Technology Division, School of Industrial Technology, Universiti Sains Malaysia, 11800 USM, \\ Penang, Malaysia
}

\author{
Article history: \\ Received: 28 January 2020 \\ Received in revised form: 28 \\ October 2020 \\ Accepted: 1 April 2021 \\ Available Online: 18 April \\ 2021 \\ Keywords: \\ Tapioca starch, \\ Acetylated, \\ Enzyme-acetylated, \\ Alcohol-enzyme acetylated, \\ Acetyl groups, \\ Degree of substitution
}

DOI:

https://doi.org/10.26656/fr.2017.5(2).038

\begin{abstract}
Surface modified tapioca starch was developed by enzyme treatment (using STARGENTM 002 enzyme) and alcohol-enzyme treatment. The effects of acetylation treatment on surface modified tapioca starches were evaluated for acetyl content (Ac\%), degree of substitution (DS), morphology using scanning electron microscopy (SEM), Fourier Transform Infrared spectroscopy (FTIR), thermal properties, and X-ray diffraction (XRD) patterns. After acetylation treatment, Ac\% and DS value of the samples were significantly increased for acetylated $(0.67 \%$ and 0.03$)$, enzyme-acetylated $(1.13 \%$ and 0.04$)$, and alcohol-enzyme acetylated $(1.76 \%$ and 0.07$)$. The acetylation treatment led to the formation of a few starch granules due to the introduction of hydrophilic groups of acetyl molecules into starch granules. The incorporation of acetyl groups into starch molecules also was shown at peak $1750 \mathrm{~cm}^{-1}, 1369 \mathrm{~cm}^{-1}$, and $1230 \mathrm{~cm}^{-1}$ in the FTIR spectra. The enzyme-acetylated and alcohol-enzyme acetylated starch granules retained the A-type crystalline structure with decreased in the gelatinization enthalpy $(\Delta H)$ after acetylation.
\end{abstract}

\section{Introduction}

Starch is one of the important materials that have been extensively used for both food and non-food applications due to abundant sources and low cost. Recently, starch and starch derivatives are widely used in the food industry as carrier materials to protect and act as encapsulating agents for volatile compounds (Robert et al., 2012; Gao et al., 2013; Najafi et al., 2016; Wang et al., 2016; Acevedo-Guevara et al., 2018). Carrier materials act as storage tool to protect sensitive ingredients such as flavors, oils, minerals, vitamins, and food pigments that are sensitive to light, oxidation or high temperature (Belingheri et al., 2015; Wang et al., 2016; Hoyos-Leyva et al., 2018; Lei et al., 2018). However, the functionality of starch as a carrier to control the release rate of ingredients is limited due to its low surface area and pore volume on the granules ( $\mathrm{Zhu}$, 2017; Zhao, Yu, Yang et al., 2018). Therefore, modification treatments are commonly applied to the surface of starch granules to achieve its intended functions.

Enzymatic treatment is one of the most preferred methods to alter the surface of the starch granules with abundant sites of erosion (Chen et al., 2011; Luo et al., 2013; Benavent-Gil and Rosell, 2017a). Enzyme such as $\alpha$-amylase (AM) and/or amyloglucosidase (AMG) are used to penetrate the surface of the starch granules. However, direct hydrolysis on the native tapioca starch granules results in low susceptibility of enzyme molecules to hydrolyze and to penetrate the surface due to the presence of fat and protein layer on the surface of the granules. For the purpose of removing both of surface fat and protein, alcohol pre-treatments may be applied to enhance the degradation of the starch by enzyme molecules (Li, Gao, Wu et al., 2016). However, the pre-treatment and enzyme penetration effects on tapioca starch granule might not be sufficient to modify the surface granules for encapsulation purpose. Therefore, further chemical modification is needed to increase the binding sites on starch granules surface.

Acetylation is one of the chemical treatments that have been used to modify starch molecules to improve their application for encapsulation purpose (Robert et al., 2012; García-Tejeda et al., 2015; Najafi et al., 2016; Acevedo-Guevara et al., 2018). Treating native starch granules with acetic anhydride (AA) helps in increasing the binding sites on the starch granules surface (GarcíaTejeda et al., 2015) and transforming hydrophilic nature of the starch molecules into slightly hydrophobic. This treatment involves the substitution mechanism where the free hydroxyl $(\mathrm{OH})$ groups in the starch chains are 
replaced by acetyl $\left(\mathrm{CH}_{3} \mathrm{COO}\right)$ groups. The $\mathrm{CH}_{3} \mathrm{COO}$ groups introduced into the starch granules allow volatile compounds to interact with the starch molecules. In view of this, the acetylated starch is considered as a promising alternative for the development of surface modified starch which helps to improve the binding sites on the starch granules for wider applications as compared to the native starch.

Several studies have developed the surface modified starches via enzyme treatment (Chen et al., 2011; Luo et al., 2013; Benavent-Gil and Rosell, 2017a; Jung et al., 2017; Lacerda et al., 2018) and combination of alcohol with enzyme treatment (Uthumporn et al., 2013). Many of the studies have shown only the effect of those treatments separately. However, the combination of acetylation with those treatments has not been investigated thus far, to produce surface modified starches. Therefore, the main objective of this study was to evaluate the effects of acetylation treatment on the surface modified tapioca starch. This study will provide useful information for future research to improve the utilization of surface modified starch in the food industry.

\section{Materials and methods}

\subsection{Materials}

Tapioca starch (Mannihot esculenta Crantz) with moisture content of $11.50 \%$, was obtained from Thye Huat Chan Sdn. Bhd. (Penang, Malaysia). Commercial STARGEN ${ }^{\text {TM }} 002$ enzyme with minimum activity 570 GAU/g and optimum pH is 4.0-4.5 (DuPont Genencor Science), produced by Aspergillus kawachi $\alpha$-amylase expressed in Trihoderma reesei and an amyloglucosidase from Trichoderma reesei were obtained from CK Chemical Sdn. Bhd. (Selangor, Malaysia).

\subsubsection{Preparation of alcohol pre-treatment}

Alcohol pre-treated starches were produced according to the method described by $\mathrm{Li}, \mathrm{Gao}, \mathrm{Wu}$ et al. (2016) using Soxhlet extraction with some modifications. Native starch was treated with $75 \%(\mathrm{w} / \mathrm{v})$ aqueous of 2-propanol for $1 \mathrm{hr}$. Then, the solvent was filtered by vacuum pump equipped with Whatman No. 3 filter paper. The starch residues were dried at $40^{\circ} \mathrm{C}$ in an oven for overnight.

\subsubsection{Enzyme hydrolysis}

The preparation of enzyme hydrolysis was based on the method of Uthumporn et al. (2012). About $25 \mathrm{~g}$ of starch (native and alcohol pre-treated) was dispersed in $100 \mathrm{~mL}$ of sodium acetate buffer $\mathrm{pH}$ 4.3. STARGEN ${ }^{\mathrm{TM}}$ 002 enzyme $(5 \%, \mathrm{w} / \mathrm{v})$ was added into the slurry and incubated for $24 \mathrm{hrs}$ in a shaking incubator (SI- 600R, Jelo Tech, South Korea) operating at $150 \mathrm{rpm}$ and $45^{\circ} \mathrm{C}$. Then, $2 \mathrm{M}$ of $\mathrm{HCl}$ solutions were added into the slurry until the $\mathrm{pH}$ reached 1.5-1.6 to stop the enzyme reactions. After that, the slurries were centrifuged (Model 4000 Centrifuge, Kubota Corporation, Japan) at $3000 \mathrm{rpm}$ for 5 mins and washed with distilled water. This procedure was repeated for several times to remove the top brown layer of samples. Their suspensions were then neutralized with distilled water and filtered (Whatman No.3 filter paper) using a vacuum pump. The starch residues were dried at $40{ }^{\circ} \mathrm{C}$ in an oven for 2 days, ground and sieved through a $75 \mu \mathrm{m}$ sieve.

\subsubsection{Preparation of acetylated starches}

The native, enzyme treatment and alcohol-enzyme treatment starches were acetylated according to the method described by García-Tejeda et al. (2015) with some modifications (Figure 1). About $50 \mathrm{~g}$ of the samples were mixed in $112 \mathrm{~mL}$ of distilled water at $25^{\circ} \mathrm{C}$ with continuous stirring using an overhead stirrer. For the acetylation reaction to take place, the $\mathrm{pH}$ of the suspension must be maintained between 8.0-8.4 with 3\% (w/v) aqueous $\mathrm{NaOH}$ solution. Then, about $20 \mathrm{~g} / 100 \mathrm{~g}$ of acetic anhydride (AA, starch dry basis) was added dropwise into the starch slurry; while still maintaining the $\mathrm{pH}$ within the range 8.0-8.4 using $3 \% \mathrm{NaOH}$ solution. After the completion of acetic anhydride addition, the reaction was continued for 15 mins and the $\mathrm{pH}$ was adjusted to 4.5 with $5 \%(\mathrm{v} / \mathrm{v}) \mathrm{HCl}$ solution. Final suspension was centrifuged at $2500 \mathrm{rpm}$ for 5 mins and neutralized by washing for several times with distilled water. The neutralized starch samples were filtered with

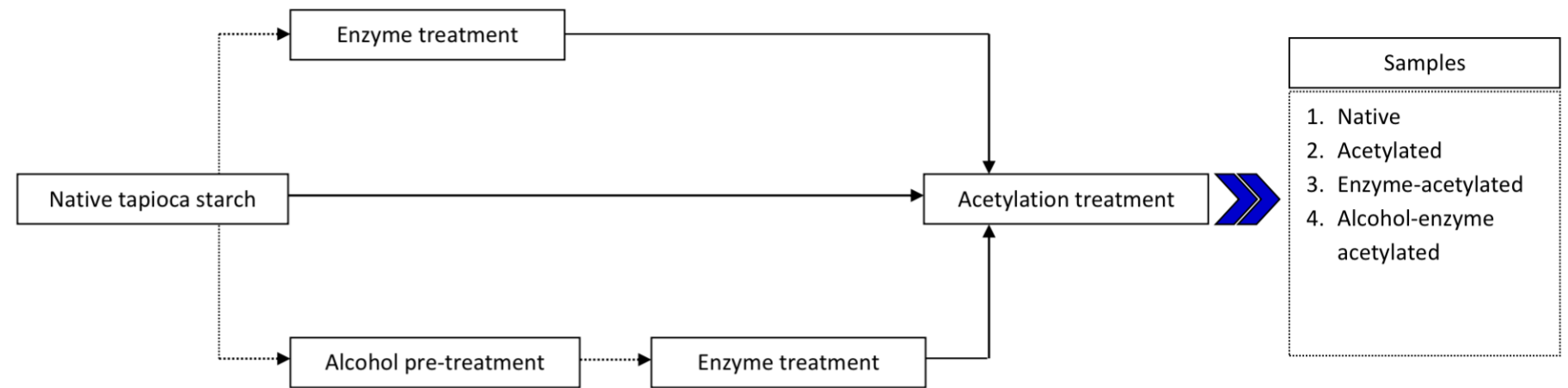

Figure 1. Schematic diagram for sample preparation of the acetylated starches. 
a filter paper (Whatman No. 3) using vacuum pump and dried in an oven at $40^{\circ} \mathrm{C}$ for 2 days. The dried samples were sieved through a $75 \mu \mathrm{m}$ sieve and kept at room temperature in airtight glass containers.

\subsection{Determination of the acetyl percentage (Ac\%) and degree of substitution (DS)}

The titration method as described by Sahnoun et al. (2016) with some modifications was used to determined $\mathrm{Ac} \%$ and DS of all the acetylated samples (i.e., acetylated starch, enzyme-acetylated starch and alcoholenzyme acetylated starch). Approximately $1.0 \mathrm{~g}$ of acetylated starch was placed in a $250 \mathrm{~mL}$ flask and mixed with $50 \mathrm{~mL}$ of distilled water. Then 5-6 drops of phenolphthalein as an indicator were added into the suspension and the solution was titrated with $0.1 \mathrm{M}$ $\mathrm{NaOH}$ solution until a permanent pink color was produced. A $25 \mathrm{~mL}$ of $0.5 \mathrm{M} \mathrm{NaOH}$ solution was added, and the mixture was shaken $(120 \mathrm{rpm})$ in incubator shaker at room temperature. After 30 mins, the excess alkali was then titrated with $0.2 \mathrm{M} \mathrm{HCl}$ solution until the pink color disappeared. The native tapioca starch was used as blank and treated in similar procedure. Ac\% and DS were calculated as follows:

$$
\begin{aligned}
& A c(\%)=\frac{\left(V_{1}-V_{2}\right) \times 10^{3} \times M \times 43 \times 100}{W} \\
& D S=\frac{(162 \times A c \%)}{[4300-(42 \times A C \%)]}
\end{aligned}
$$

Where $V_{l}=$ volume of $0.2 \mathrm{M} \mathrm{HCl}$ used for titration of native tapioca starch; $V_{2}=$ volume of $0.2 \mathrm{M} \mathrm{HCl}$ used for titration of acetylated starch; $\mathrm{M}=$ molarity of $\mathrm{HCl}$ solution; $\mathrm{W}=$ weight of the acetylated starch; $43=$ molecular weight of the acetyl group, $\mathrm{g} / \mathrm{mol} ; 162=$ molecular weight of an anhydroglucose unit, $\mathrm{g} / \mathrm{mol}$.

\subsection{Granule properties}

The granule surfaces of native and acetylated starches were observed using a scanning electron microscope (Quanta 650 FEG, FEI Company, Netherlands) using a magnification of $3000 \mathrm{x}$ and an acceleration voltage of $10 \mathrm{kV}$. The dried samples were spread on the surface of double-sided adhesive tape fixed on aluminum specimen stub and coated with a thin layer of gold before examined.

\subsection{Fourier transforms infrared (FTIR) spectroscopy}

A formation of new functional groups and any changes in the chemical structure of starch samples after acetylation were analyzed using a Fourier Transform Infrared (FTIR) spectrometer (Nicolet iS10, Thermo Fisher Scientific, USA). About $1 \mathrm{mg}$ of dried samples was pressed as a pellet with $100 \mathrm{mg}$ of dried potassium bromide $(\mathrm{KBr})$. The samples were scanned for a total of 32 scans from wavenumber of $4000 \mathrm{~cm}^{-1}$ to $400 \mathrm{~cm}^{-1}$.
The spectra of the surface acetylated starch samples obtained were then recorded and compared with the spectra of the native starch.

\subsection{X-ray diffraction $(X R D)$ spectroscopy}

The X-ray diffraction (XRD) of the native and acetylated starches samples were determined using X-ray diffractometry (D8 Advance, Brucker, AXS, Germany), while the degree of crystallinity (\%) was calculated using the Bruker Difrrac. Eva (version 4). The dried samples were conditioned at $100 \%$ relative humidity $(\mathrm{RH})$ at room temperature for overnight before observation (Uthumporn et al., 2012). Then, these samples were scanned in an angular range from 4 to $40^{\circ}(2 \theta)$; step size, $0.02^{\circ}$; step times, $0.1 \mathrm{~s}$ per step. The $\mathrm{Cu} \mathrm{K} \alpha$ radiation $(\lambda$ $=1.5406 \AA$ ) was set at $40 \mathrm{kV}$ (tube voltage) and $40 \mathrm{~mA}$ (tube current) using nickel-filtering. The diffracted radiation was detected using a proportional detector.

\subsection{Thermal properties}

The thermal properties of the samples were analyzed using a differential scanning calorimetry (DSC Q100, TA Instruments, USA). About $2.5 \mathrm{mg}$ (dry basis) of each sample was placed into a hermetic aluminium pan and distilled water was then added to produce starch-water ratio of 1:3 (g/g) (Benavent-Gil and Rosell, 2017b). Then, the sample pan was sealed and equilibrated at $25^{\circ}$ $\mathrm{C}$ for $1 \mathrm{hr}$ prior to DSC testing. The sample pan was heated from $20^{\circ} \mathrm{C}$ to $130^{\circ} \mathrm{C}$ with heating rate of $10^{\circ} \mathrm{C} /$ $\mathrm{min}, 50 \mathrm{~mL} / \mathrm{min}$ of nitrogen flow rate and an empty aluminium pan was used as a reference. The onset $\left(T_{o}\right)$, peak $\left(T_{p}\right)$, and conclusion $\left(T_{c}\right)$ temperatures were analyzed based on the heating curves, while the gelatinization enthalpy $(\Delta H)$ was determined based on the area between the connection points of $T_{o}$ and $T_{c}$ and is expressed in $\mathrm{J} / \mathrm{g}$ (dry basis) in Universal Analysis 2000 software (TA Instruments, USA).

\subsection{Statistical analysis}

Data are presented as mean \pm standard deviation. All data were analyzed by one-way ANOVA and the significant differences among the samples were determined using Turkey's HSD test $(\alpha=0.05)$ by SPSS Statistics for Window (Version 20.0, IBM Corporation, USA).

\section{Results and discussion}

\subsection{Acetyl percentage and degree substitution}

The acetyl groups percentage (Ac\%) and degree of substitution (DS) of the native, acetylated, enzymeacetylated and alcohol-enzyme acetylated surface modified starches are presented in Table 1 . The Ac\% and DS values of the samples ranged between 0.67 to 1.76 
$\mathrm{g} / 100 \mathrm{~g}$, and 0.03 to 0.07 , respectively. The obtained $\mathrm{Ac} \%$ in the starch samples are within the maximum value $(2.5 \mathrm{~g} / 100 \mathrm{~g})$ as recommend by the US Food and Drug Administration (US FDA) for food applications. Moreover, the acetylated starch samples were classified as medium DS (0.1-1.0), obtained by esterification of the native starch with acetic anhydride in an aqueous medium in the presence of an alkaline catalyst (3\% of $\mathrm{NaOH}$ solution) (Colussi et al., 2015).

Table 1. Acetyl percentage (Ac\%) and degree of substitution (DS) of the treated acetylation tapioca starches.

\begin{tabular}{lcc}
\hline Treatments & $\mathrm{Ac} \%$ & $\mathrm{DS}$ \\
\hline Native & - & - \\
Acetylated & $0.67 \pm 0.04^{\mathrm{a}}$ & $0.03 \pm 0.00^{\mathrm{a}}$ \\
Enzyme-acetylated & $1.13 \pm 0.13^{\mathrm{b}}$ & $0.04 \pm 0.01^{\mathrm{b}}$ \\
Alcohol-enzyme acetylated & $1.76 \pm 0.11^{\mathrm{c}}$ & $0.07 \pm 0.00^{\mathrm{c}}$ \\
\hline
\end{tabular}

Values are expressed as mean \pm SD. Values with different superscript within column are significantly different $(\mathrm{p}<0.05)$.

After acetylation treatment, both the surface modified starch samples showed significantly higher values of $\mathrm{Ac} \%$ and $\mathrm{DS}$ as compared to the native and acetylated starches. This may be attributed to the presence of more free hydroxyl $(\mathrm{OH})$ groups in the starch molecules which could be substituted with acetyl groups during acetylation (Zhang et al., 2010; Sahnoun et al., 2016; Zhao, Saleh, Li et al., 2018). This increase could be caused by surface erosion after enzyme hydrolysis during surface modification treatment. The presence of enzyme would disrupt and weakens the hydrogen bonds in the starch granules, resulting in deep erosion on the surface, in turn, increased surface area; which makes it easier for acetic anhydride to interact with the starch granules (Zhao, Saleh, Li et al., 2018).

Besides, alcohol-enzyme acetylated starch had the highest Ac\% and DS values compared to the enzymeacetylated starch which could be due to the disruption of amorphous regions by alcohol reagents before enzyme penetration (Li, Gao, Wu et al., 2016). This could allow for the greatest penetration of the enzyme into the surface granules, resulting in deep surface erosion and increased free $\mathrm{OH}$ groups. Therefore, more acetyl groups would be substituted in the starch molecules during acetylation treatment. Differences in Ac\% and DS values might be attributed to the type of treatments and structures of the starch granules.

\subsection{Morphology properties}

The granular structures of the native and the treated acetylation starches are shown in Figure 2. Based on Figure 2a, the native starch granules had a smooth surface with one or more truncated area on the surface. Similar morphology of native tapioca starch granules was reported by (Mbougueng et al., 2012; Alzate et al., 2016), where the surface granules were smooth without any pores or cracks. After acetylation, the surface granules of the native starch became rough (Figure 2b). In addition, surface erosion was also observed on some granules, possibly due to the penetration of acetic anhydride on the surface of the smooth granules (Chiu and Solarek, 2009; Mendoza et al., 2016). The SEM shows no obvious changes in the size and the shape of the starch granules after acetylation.
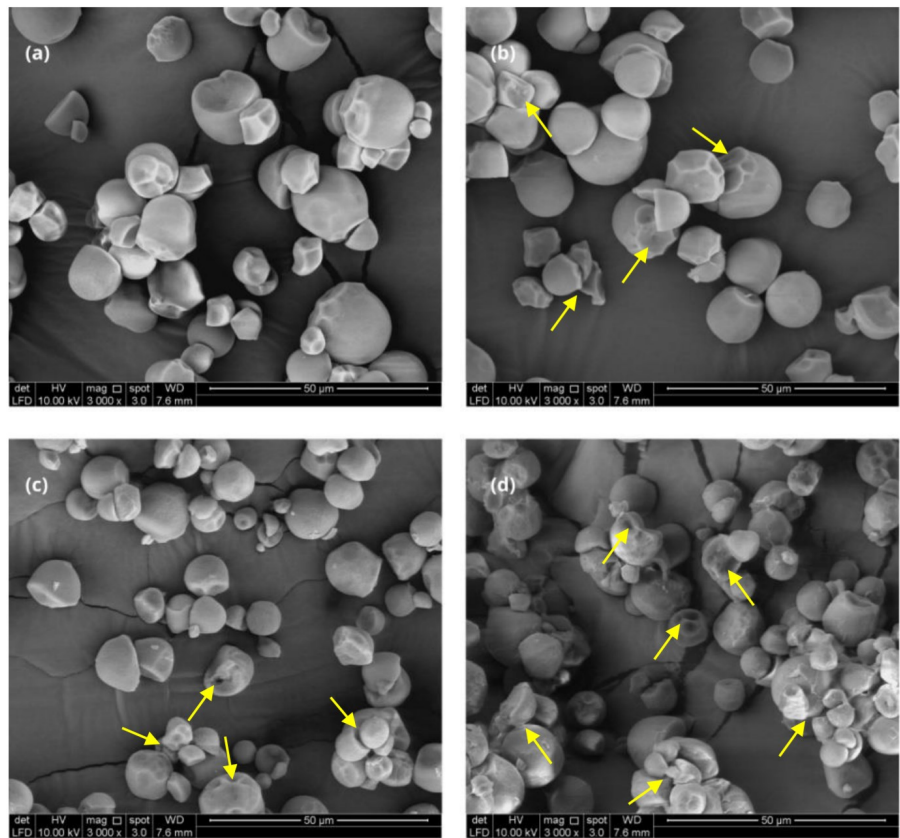

Figure 2. Scanning electron microscopic photographs for the (a) native; (b) acetylated; (c) enzyme-acetylated; (d) alcoholenzyme acetylated. Defects of the structure due to the treatments are shown by yellow arrow.

On the other hand, the surface of enzyme-acetylated starch granules became rough and deep erosion occurred after acetylation treatment than that of the surface of their native state (Figure 2c). Enzyme molecules are believed to penetrate the surface of the starch granules during hydrolysis process and could have promoted the deep erosion on the surface of the granules (BenaventGil and Rosell, 2017b; Lacerda et al., 2018). Such surface granules had erosion, allowing greater penetration of acetic anhydride on the granule surface, resulting in deep surface erosion. In addition, a few starch granules were found to clump to each other after acetylation due to the incorporation of acetyl groups to the starch molecules, resulting in high hydrogen bonding (Singh et al., 2004; Mbougueng et al., 2012).

After acetylation treatment, deep surface erosion, rough surface and fusion of few starch granules were observed in the alcohol-enzyme acetylated samples (Figure 2d) as compared to the enzyme-acetylated sample. The deep erosion on the surface of the granules might be due to the influence of alcohol pre-treatment 
followed by enzyme treatment. According to Uthumporn et al. (2013) and $\mathrm{Li}, \mathrm{Gao}, \mathrm{Wu}$ et al. (2016), alcohol reagent could interrupt and weaken hydrogen bonds of the starch molecules, in turn, weakened the granules structures. Therefore, the enzyme molecules can easily penetrate the granules through the weakened granules structures, resulting in the formation of deep erosion on the surface. Besides, the presence of fused starch granules might be due to the introduction of hydrophilic groups of acetyl molecules after acetylation process to the starch molecules.

Based on the results, acetylation treatment had caused mild changes on the surface of the granules as compared to the native starch, with expectation of the formation of a few fused starch granules (Singh et al., 2004; Mbougueng et al., 2012; Zhao, Saleh, Li et al., 2018). The effect of acetylation on the surface of starch granules might be depending on the sources of starch and the pre-treatment conditions.

\subsection{Fourier transforms infrared analysis}

The FTIR spectra of starch samples are shown in Figure 3. In the spectra of native tapioca starch, the peak around $3000-3600 \mathrm{~cm}^{-1}$ was observed which attributed to the hydroxyl groups $(\mathrm{O}-\mathrm{H})$ in the starch molecules. In addition, the absorption bands at $2929 \mathrm{~cm}^{-1}, 1653 \mathrm{~cm}^{-1}$, $1159 \mathrm{~cm}^{-1}$ and $1010 \mathrm{~cm}^{-1}$ were also observed in this study, which related to $\mathrm{C}-\mathrm{H}_{2}$ stretching bonds, C-O-O stretching vibration in carbohydrate groups, $\mathrm{C}-\mathrm{O}$ bonds and C-C bonds, respectively (Rahim and Kadir, 2017).

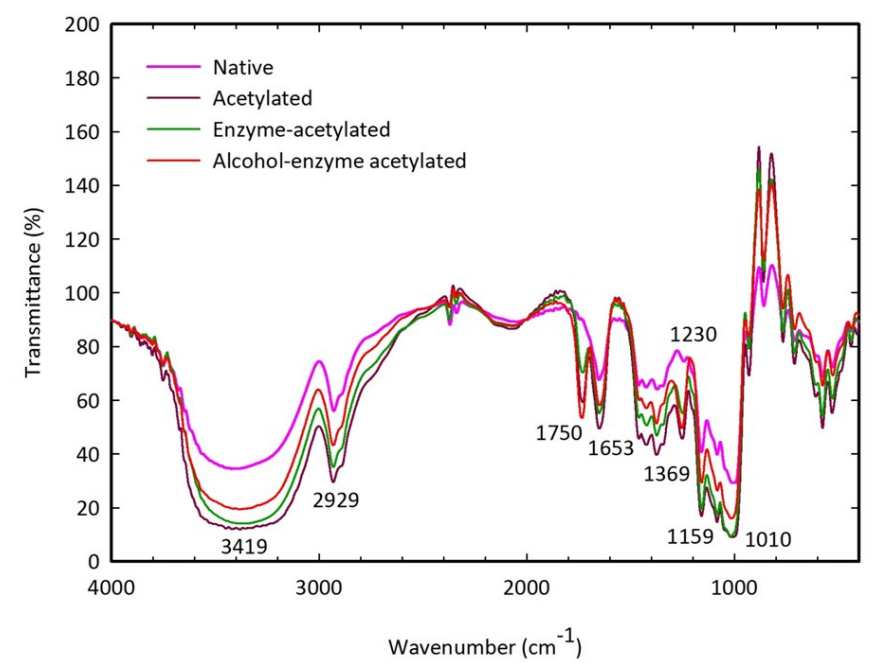

Figure 3. FTIR spectra of the native and the treated acetylation tapioca starches.

The molecular structure of the treated acetylation starch samples showed no significant changes compared to the native starch, but the presences of new bands clearly indicated the introduction of acetyl group in the spectra was detected. Similar observation on the new absorption peaks after acetylation treatment was reported by several researchers (Mbougueng et al., 2012; Colussi et al., 2015; Mendoza et al., 2016). After acetylation treatment, a new peak at $1750 \mathrm{~cm}^{-1}$, which attributed to the $\mathrm{C}=\mathrm{O}$ bonds, and strong absorption peaks at $1369 \mathrm{~cm}^{-1}$ attributed $\mathrm{C}-\mathrm{H}$ bond in acetyl group and $1230 \mathrm{~cm}^{-1} \mathrm{C}-\mathrm{O}$ of acetyl groups were observed. These new bands confirmed the presence of acetyl groups and they are covalently bounds to the starch molecules (Mbougueng et al., 2012; Colussi et al., 2015; Rahim and Kadir, 2017; Shah et al., 2017). The absence of absorption bands at peaks $1750 \mathrm{~cm}^{-1}, 1369 \mathrm{~cm}^{-1}$ and $1230 \mathrm{~cm}^{-1}$ in the spectrum of the native tapioca starch indicated that the sample was free of acetylation process.

However, reduction in the intensity at peak 3000 $3600 \mathrm{~cm}^{-1}$ after acetylation treatment could be due to the substitution of $\mathrm{O}-\mathrm{H}$ groups with acetyl groups in the starch molecules (Hong et al., 2016; Rahim and Kadir, 2017). The intensity of those bands decreased as a consequence of the increasing DS value and also acetyl groups, which were introduced in the starch molecules. Therefore, after acetylation treatments, the samples had stronger intensity peaks at $1750 \mathrm{~cm}^{-1}(\mathrm{C}=\mathrm{O}), 1369 \mathrm{~cm}^{-1}$ (C-H) and $1230 \mathrm{~cm}^{-1}$ (C-O). Based on the comparison among the treatments, the FTIR results for the alcoholenzyme acetylated starch exhibited the stronger $\mathrm{C}=\mathrm{O}$ bonds and narrow band at the $\mathrm{C}-\mathrm{H}$ and $\mathrm{C}-\mathrm{O}$ bonds, suggesting that more free $\mathrm{O}-\mathrm{H}$ groups in the starch molecules were converted into acetyl groups. These results are in accordance with the Ac\% and DS results, which showed significantly higher Ac\% and DS values in the alcohol-enzyme acetylated tapioca starches than the acetylated and enzyme-acetylated starches.

\subsection{X-ray diffraction (XRD)}

The crystallinity characteristics of the starch samples were studied using XRD analysis. The XRD patterns of the native and the treated acetylation tapioca starch samples are shown in Figure 4. The native tapioca starch showed four strong diffraction peaks at $2 \theta$ about $15^{\circ}$ and $23^{\circ}$, a connected double peak at $17^{\circ}$ and $18^{\circ}$, and a small peak at $19^{\circ}$, characteristic of type A tuber starches (Li, Liu, Gao et al., 2016; Zhang et al., 2017). As can be seen in Figure 4, the diffractograms of the treated acetylation starch samples showed a similar A-type pattern when compared to the native tapioca starch. This observation suggests that the acetylation treatment did not alter the crystalline pattern of the starch (Rahim and Kadir, 2017).

On the other hand, a reduction in diffraction peaks intensity of the treated tapioca was observed after acetylation treatment. Similar observations were reported by Kong et al. (2016) and Zhao, Saleh, Li et al. (2018) for the reduction of the diffraction peaks intensity of treated acetylation starches. The introduction of acetyl groups by the acetic anhydride into the starch granules 
could destroy of double helices structures of the starch molecules. Meanwhile, the treatment of enzyme and alcohol-enzyme led to change in the amylose and amylopectin arrangement of the treated starch granules.

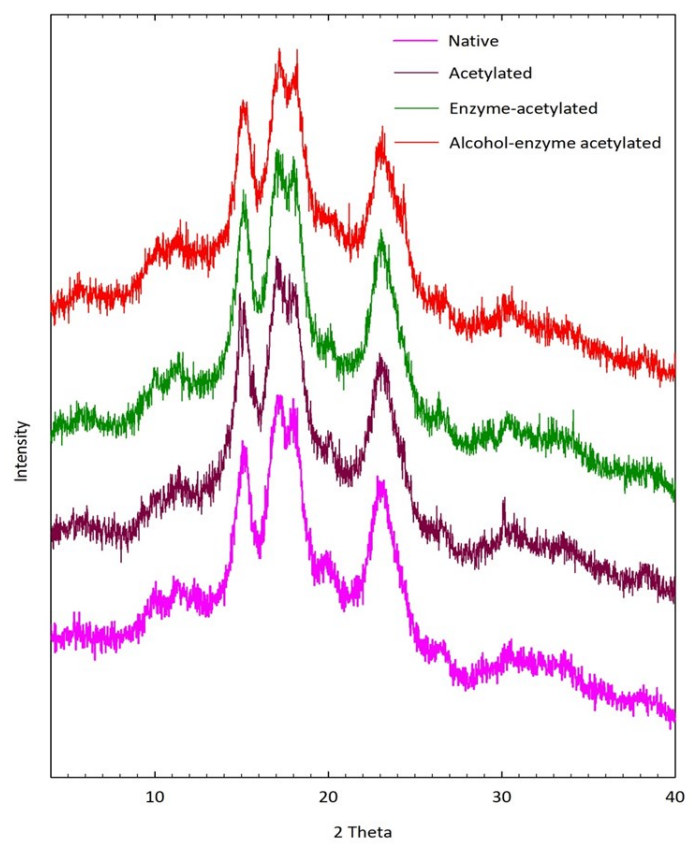

Figure 4. X-ray diffractograms for the native and the treated acetylation tapioca starches.

\subsection{Thermal properties}

The thermal properties of the native starch and the treated acetylation starches are shown in Table 2. Results from the table show that the value of onset temperature (To) was not significant after acetylation treatment, except the enzyme-acetylated sample. This may be attributed to the penetration of enzyme molecules on the surface of the granules before acetylation which led to the disruption of the crystalline and amorphous areas of the starch chain (Jung et al., 2017) before acetylation treatment. However, the peak temperatures $\left(T_{p}\right)$ tended to decrease due to the acetylation treatment introduced on the starch samples. Similar observations were reported by Zhao, Saleh, Li et al. (2018) for the $T_{p}$ value of treated starches followed by acetylation treatment.

On the other hand, the gelatinization enthalpy, $\Delta H$ tended to decrease after acetylation treatment compared with the native tapioca starch. The highest DS values of the starch samples result in the greatest reduction in $\Delta H$ which was obtained from the alcohol-enzyme acetylated sample. Besides, it was found that the presence of acetyl groups in the starch molecules change the double helices structures (El Halal et al., 2015). This result was expected as the substitution of acetyl groups in the starch molecules had caused damage and altered the double helices structures. Furthermore, the decrease in hydroxyl groups as a result of the substitution of acetyl groups indicates the weakening of the internal hydrogen bonding of starch. Besides, the decrease in $\Delta H$ of the treated samples might be attributed to the alteration of double helices by the enzyme and alcohol-enzyme, which caused destabilization of the starch granules. Similar results were obtained by Zhao, Saleh, Li et al. (2018) for pre-treated wheat starch prior to acetylation treatment.

\section{Conclusion}

In this study, the effects of acetylation treatment the native, enzyme treatment and alcohol-enzyme treatment tapioca starches were investigated. After acetylation treatment, the $\mathrm{Ac} \%$ and DS value of the enzymeacetylated and the alcohol-enzyme acetylated starches were found significantly increased as compared to the starch that underwent only acetylation treatment. Increasing in the $\mathrm{Ac} \%$ and DS value of the treated acetylation starches had caused significant reduction in the $\Delta H$ value in the following order: native $>$ acetylated $>$ enzyme-acetylated $>$ alcohol-enzyme acetylated. The scanning electron micrographs showed erosion on the starch granules for the enzyme-acetylated and the alcohol-enzyme acetylated starches. The introduction of hydrophilic groups of acetyl molecules into the starch granules had caused starch granules to clump to each other. In our study, it is shown that enzyme and alcoholenzyme treatment may serve as an additional step to the acetylation treatment of the starch to improve the properties of the starch for industrial application. However, the suitability of the treated acetylation tapioca starches for food industrial applications needs to be investigated in future studies.

\section{Conflict of interest}

The authors declare no conflict of interest.

Table 2. Thermal properties of the starch samples.

\begin{tabular}{lcccc}
\hline \multirow{2}{*}{ Type of treatments } & \multicolumn{4}{c}{ DSC properties } \\
\cline { 2 - 5 } & $T_{o}\left({ }^{\circ} \mathrm{C}\right)$ & $T_{p}\left({ }^{\circ} \mathrm{C}\right)$ & $T_{c}\left({ }^{\circ} \mathrm{C}\right)$ & $\Delta H(\mathrm{~J} / \mathrm{g})$ \\
\hline Native & $56.24 \pm 2.04^{\mathrm{a}}$ & $67.05 \pm 1.11^{\mathrm{c}}$ & $74.92 \pm 2.73^{\mathrm{a}}$ & $7.71 \pm 0.18^{\mathrm{b}}$ \\
Acetylated & $56.23 \pm 1.60^{\mathrm{a}}$ & $62.71 \pm 0.79^{\mathrm{b}}$ & $71.17 \pm 1.32^{\mathrm{a}}$ & $1.61 \pm 0.09^{\mathrm{a}}$ \\
Enzyme-acetylated & $60.91 \pm 2.11^{\mathrm{b}}$ & $66.07 \pm 2.23^{\mathrm{bc}}$ & $74.39 \pm 3.44^{\mathrm{a}}$ & $1.64 \pm 0.59^{\mathrm{a}}$ \\
Alcohol-enzyme acetylated & $53.79 \pm 1.29^{\mathrm{a}}$ & $58.69 \pm 1.20^{\mathrm{a}}$ & $74.36 \pm 2.07^{\mathrm{a}}$ & $1.35 \pm 0.43^{\mathrm{a}}$ \\
\hline
\end{tabular}

Values are expressed as mean \pm SD. Values with different superscript within column are significantly different ( $<<0.05)$. 


\section{Acknowledgement}

The authors are gratefully acknowledge the Ministry of Higher Education Malaysia (MOHE) for providing financial support through the Fundamental Research Grant Scheme (FRGS) [203/PTEKIND/6711635].

\section{References}

Acevedo-Guevara, L., Nieto-Suaza, L., Sanchez, L.T., Pinzon, M.I. and Villa, C.C. (2018). Development of native and modified banana starch nanoparticles as vehicles for curcumin. International Journal of Biological Macromolecules, 111, 498-504. https:// doi.org/10.1016/j.ijbiomac.2018.01.063

Alzate, P., Zalduendo, M.M., Gerschenson, L. and Flores, S.K. (2016). Micro and nanoparticles of native and modified cassava starches as carriers of the antimicrobial potassium sorbate. Starch-Stärke, 68(11-12), 1038-1047. https://doi.org/10.1002/ star.201600098

Belingheri, C., Ferrillo, A. and Vittadini, E. (2015). Porous starch for flavor delivery in a tomato-based food application. LWT-Food Science and Technology, 60(1), 593-597. https://doi.org/10.1016/ j.lwt.2014.09.047

Benavent-Gil, Y. and Rosell, C.M. (2017a). Comparison of porous starches obtained from different enzyme types and levels. Carbohydrate Polymers, 157, 533540. https://doi.org/10.1016/j.carbpol.2016.10.047

Benavent-Gil, Y. and Rosell, C.M. (2017b). Morphological and physicochemical characterization of porous starches obtained from different botanical sources and amylolytic enzymes. International Journal of Biological Macromolecules, 103, 587595. https://doi.org/10.1016/j.ijbiomac.2017.05.089

Chen, Y., Huang, S., Tang, Z., Chen, X. and Zhang, Z. (2011). Structural changes of cassava starch granules hydrolyzed by a mixture of $\alpha$-amylase and glucoamylase. Carbohydrate Polymers, 85(1), 272275. https://doi.org/10.1016/j.carbpol.2011.01.047

Chiu, C. and Solarek, D. (2009). Modification of starches. In BeMiller, J. and Whistler, R. (Eds). Starch. Chemistry and Technology, p. 629-655. New York: Academic Press. https://doi.org/10.1016/B978 -0-12-746275-2.00017-3

Colussi, R., El Halal, S.L.M., Pinto, V.Z., Bartz, J., Gutkoski, L.C., da Rosa Zavareze, E. and Dias, A.R.G. (2015). Acetylation of rice starch in an aqueous medium for use in food. LWT-Food Science and Technology, 62(2), 1076-1082. https:// doi.org/10.1016/j.lwt.2015.01.053

El Halal, S.L., Colussi, R., Pinto, V.Z., Bartz, J., Radunz, M., Carreño, N.L., Dias, A.R. and Zavareze Eda, R.
(2015). Structure, morphology and functionality of acetylated and oxidised barley starches. Food Chemistry, 168, 247-256. https://doi.org/10.1016/ j.foodchem.2014.07.046

Gao, F., Li, D., Bi, C.-H., Mao, Z.-H. and Adhikari, B. (2013). The adsorption and release characteristics of CPFX in porous starch produced through different drying methods. Drying Technology, 31(13-14), 1592-1599. doi.org/10.1080/07373937.2013.815627

https://

García-Tejeda, Y.V., Salinas-Moreno, Y. and MartínezBustos, F. (2015). Acetylation of normal and waxy maize starches as encapsulating agents for maize anthocyanins microencapsulation. Food and Bioproducts Processing, 94, 717-726. https:// doi.org/10.1016/j.fbp.2014.10.003

Hong, J., Chen, R., Zeng, X.-A. and Han, Z. (2016). Effect of pulsed electric fields assisted acetylation on morphological, structural and functional characteristics of potato starch. Food Chemistry, 192, 15-24. https://doi.org/10.1016/ j.foodchem.2015.06.058

Hoyos-Leyva, J.D., Bello-Pérez, L.A., Alvarez-Ramirez, J. and Garcia, H.S. (2018). Microencapsulation using starch as wall material: A review. Food Reviews International, 34(2), 148-161. https:// doi.org/10.1080/87559129.2016.1261298

Jung, Y.S., Lee, B.H. and Yoo, S.H. (2017). Physical structure and absorption properties of tailor-made porous starch granules produced by selected amylolytic enzymes. PloS one, 12(7), e0181372. https://doi.org/10.1371/journal.pone.0181372

Kong, X., Zhou, X., Sui, Z. and Bao, J. (2016). Effects of gamma irradiation on physicochemical properties of native and acetylated wheat starches. International Journal of Biological Macromolecules, 91, 11411150. https://doi.org/10.1016/j.ijbiomac.2016.06.072

Lacerda, L.D., Leite, D.C., Soares, R.M. and da Silveira, N.P. (2018). Effects of $\alpha$-Amylase, Amyloglucosidase, and Their Mixture on Hierarchical Porosity of Rice Starch. Starch-Stärke, 70(11-12), 1800008. https://doi.org/10.1002/ star.201800008

Lei, M., Jiang, F.C., Cai, J., Hu, S., Zhou, R., Liu, G., Wang, Y.H., Wang, H.B., He, J.R. and Xiong, X.G. (2018). Facile microencapsulation of olive oil in porous starch granules: Fabrication, characterization, and oxidative stability. International Journal of Biological Macromolecules, 111, 755-761. https:// doi.org/10.1016/j.ijbiomac.2018.01.051

Li, H., Liu, Y., Gao, X. and Li, X. (2016). Preparation and characterization of cassava starch-based 
adsorbents for separating of azeotropic ethanol-water in biofuels ethanol production. Journal of Chemical Technology and Biotechnology, 91(4), 977-984. https://doi.org/10.1002/jctb.4666

Li, W., Gao, J., Wu, G., Zheng, J., Ouyang, S., Luo, Q. and Zhang, G. (2016). Physicochemical and structural properties of A-and B-starch isolated from normal and waxy wheat: Effects of lipids removal. Food Hydrocolloids, 60, 364-373. https:// doi.org/10.1016/j.foodhyd.2016.04.011

Luo, Z., Cheng, W., Chen, H., Fu, X., Peng, X., Luo, F. and Nie, L. (2013). Preparation and properties of enzyme-modified cassava starch-zinc complexes. Journal of Agricultural and Food Chemistry, 61(19), 4631-4638. https://doi.org/10.1021/jf4016015

Mbougueng, P., Tenin, D., Scher, J. and Tchiégang, C. (2012). Influence of acetylation on physicochemical, functional and thermal properties of potato and cassava starches. Journal of Food Engineering, 108 (2), 320-326. https://doi.org/10.1016/ j.jfoodeng.2011.08.006

Mendoza, J.S., Díaz, R., Hernández, J. and Quintero, A.F. (2016). Effect of the acetylation process on native starches of yam (Dioscorea spp.). Revista Facultad Nacional De Agronomía Medellín, 69(2), 7997-8006.

https://doi.org/10.15446/ rfna.v69n2.59144

Najafi, S.H.M., Baghaie, M. and Ashori, A. (2016). Preparation and characterization of acetylated starch nanoparticles as drug carrier: Ciprofloxacin as a model. International Journal of Biological Macromolecules, 87, 48-54. https://doi.org/10.1016/ j.ijbiomac.2016.02.030

Rahim, A. and Kadir, S. (2017). The influence degree of substitution on the physicochemical properties of acetylated arenga starches. International Food Research Journal, 24(1), 102.

Robert, P., García, P., Reyes, N., Chávez, J. and Santos, J. (2012). Acetylated starch and inulin as encapsulating agents of gallic acid and their release behaviour in a hydrophilic system. Food Chemistry, 134(1), $\quad 1-8 . \quad$ https://doi.org/10.1016/ j.foodchem.2012.02.019

Sahnoun, M., Ismail, N. and Kammoun, R. (2016). Enzymatically hydrolysed, acetylated and dually modified corn starch: physico-chemical, rheological and nutritional properties and effects on cake quality. Journal of Food Science and Technology, 53(1), 481 -490. https://doi.org/10.1007/s13197-015-1984-z

Shah, A., Masoodi, F., Gani, A. and Ashwar, B.A. (2017). Physicochemical, rheological and structural characterization of acetylated oat starches. LWT-
Food Science and Technology, 80, 19-26. https:// doi.org/10.1016/j.lwt.2017.01.072

Singh, N., Chawla, D. and Singh, J. (2004). Influence of acetic anhydride on physicochemical, morphological and thermal properties of corn and potato starch. Food Chemistry, 86(4), 601-608. https:// doi.org/10.1016/j.foodchem.2003.10.008

Uthumporn, U., Karim, A. and Fazilah, A. (2013). Defatting improves the hydrolysis of granular starch using a mixture of fungal amylolytic enzymes. Industrial Crops and Products, 43, 441-449. https:// doi.org/10.1016/j.indcrop.2012.07.060

Uthumporn, U., Shariffa, Y., Fazilah, A. and Karim, A. (2012). Effects of $\mathrm{NaOH}$ treatment of cereal starch granules on the extent of granular starch hydrolysis. Colloid and Polymer Science, 290(15), 1481-1491. https://doi.org/10.1007/s00396-012-2674-2

Wang, H., Lv, J., Jiang, S., Niu, B., Pang, M. and Jiang, S. (2016). Preparation and characterization of porous corn starch and its adsorption toward grape seed proanthocyanidins. Starch-Stärke, 68(11-12), 12541263. https://doi.org/10.1002/star.201600009

Zhang, B., Mei, J.Q., Chen, B. and Chen, H.Q. (2017). Digestibility, physicochemical and structural properties of octenyl succinic anhydride-modified cassava starches with different degree of substitution. Food Chemistry, 229, 136-141. https:// doi.org/10.1016/j.foodchem.2017.02.061

Zhang, S.D., Zhang, Y.R., Huang, H.X., Yan, B.Y., Zhang, X. and Tang, Y. (2010). Preparation and properties of starch oxalate half-ester with different degrees of substitution. Journal of Polymer Research, 17(1), 43-51. https://doi.org/10.1007/ s10965-009-9288-5

Zhao, A.Q., Yu, L., Yang, M., Wang, C.J., Wang, M.M. and Bai, X. (2018). Effects of the combination of freeze-thawing and enzymatic hydrolysis on the microstructure and physicochemical properties of porous corn starch. Food Hydrocolloids, 83, 465472. https://doi.org/10.1016/j.foodhyd.2018.04.041

Zhao, K., Saleh, A.S., Li, B., Wu, H., Liu, Y., Zhang, G. and Li, W. (2018). Effects of conventional and microwave pretreatment acetylation on structural and physicochemical properties of wheat starch. International Journal of Food Science and Technology, 53(11), 2515-2524. https:// doi.org/10.1111/ijfs.13845

Zhu, F. (2017). Encapsulation and delivery of food ingredients using starch based systems. Food Chemistry, 229, 542-552. https://doi.org/10.1016/ j.foodchem.2017.02.101 